$\mathrm{UH}$

iti

Universität Hamburg
Faculty Economics and Social Sciences

Chair for Economic Policy

SEBASTIAN BRANDT / WOLFGANG MAENNIG / FELIX RICHTER

DO PLACES OF WORSHIP AFFECT HOUSING PRICES? EVIDENCE FROM GERMANY

Urban

Transport

Media

Sports

Socio-

Regional

Real Estate

Architectural

ECONOMIC DISCUSSIONS 
Hamburg Contemporary Economic Discussions

University of Hamburg

Faculty Economics and Social Science

Chair for Economic Policy

Von-Melle-Park 5

D-20146 Hamburg | Germany

Tel +49 $4042838-4622$

Fax $+494042838-6251$

http://www.uni-hamburg.de/economicpolicy/maennig.htm

Editor: Wolfgang Maennig

Sebastian Brandt

University of Hamburg

Faculty Economics and Social Science

Chair for Economic Policy

Von-Melle-Park 5

D-20146 Hamburg | Germany

sebastian_brandt@gmx.de

Wolfgang Maennig

University of Hamburg

Faculty Economics and Social Science

Chair for Economic Policy

Von-Melle-Park 5

D-20146 Hamburg | Germany

Tel +49 $4042838-4622$

Fax +494042838 - 6251

wolfgang.maennig@wiso.uni-hamburg.de

Felix Richter

University of Hamburg

Faculty Economics and Social Science

Chair for Economic Policy

Von-Melle-Park 5

D-20146 Hamburg | Germany

Tel +49 4042838 - 4628

Fax +494042838 - 6251

felix.richter@wiso.uni-hamburg.de

ISSN 1865 - 2441 (Print)

ISSN 1865 - 7133 (Online)

ISBN 978-3-942820-10-3 (Print)

ISBN 978-3-942820-11-0 (Online) 


\title{
Do places of worship affect housing prices? Evidence from Germany
}

\begin{abstract}
Using hedonic pricing models, this paper analyzes the impact of places of worship on the prices of adjacent condominiums in Hamburg, Germany. This is the first study on this subject to have been conducted outside the United States. It is also the first work to examine the externalities of places of worship of all five world religions. Furthermore, it is the first study that analyzes the effect of bell ringing on the adjacent residential property prices. Controlling for spatial dependence and by using potentiality variables positive externalities of places of worship within a radius of 1,000m were identified. Compared to properties beyond this threshold, price premiums of $4.8 \%$ were detected for condominiums at distances of $100 \mathrm{~m}$ to $200 \mathrm{~m}$ to the next place of worship. The results also show that the positive externalities near mosques do not differ from those of places of worship of other religions and that the positive effect of churches continues to be felt even after they have been deconsecrated. The influence of church bell ringing on the prices of surrounding residential properties, however, could not be substantiated.
\end{abstract}

Keywords: hedonic pricing, places of worship, external effects, residential property prices, Hamburg.

JEL classification: R12; R21; R31; R34; Z12

Version: January 2013

\section{Introduction}

The fact that places of worship (POWs) create externalities is not disputed in the literature or by local residents. However, there is disagreement on whether the externalities are positive or negative. While Do, Wilbur, and Short (1994) have identified a negative effect of churches on adjacent residential property prices, Carroll, Clauretie, and Jensen (1996) find a positive effect of churches on the prices of nearby single-family houses. While complaints from local residents against liturgical ringing or the marking of time by bells keep the courts busy, the discussion on the construction of minarets and the muezzin's call have triggered political debates. Possible further negative externalities of places of worship, such as noise caused by the arrival or departure of visitors or through community and cultural events, as well as architectural disharmony with the surrounding 
buildings are also being considered (Do, Wilbur, and Short 1994). Possible positive externalities are visual amenities that originate in Hamburg from the many old churches built in the 19th century and the green belt that surrounds many of these places of worship. Other positive effects could be created by access to services, community events and recreational activities for the young and old (Carroll, Clauretie, and Jensen 1996; Do, Wilbur, and Short 1994), as well as by the reduction in crime rates (Lee and Ousey 2005).

The fact that residential property markets value externalities of churches has been confirmed on the basis of hedonic pricing only in a few studies on U.S. markets. ${ }^{1}$ Do, Wilbur, and Short (1994) observed a negative influence of churches on the prices of neighboring single-family homes within a radius of approx. 850 feet in a community in the metropolitan region of San Diego, California. Maximum price discounts identified amount to $3.0 \%$. These findings are contradicted by Carroll, Clauretie and Jensen (1996), who found a positive influence of churches on the prices of single-family homes in the neighborhood in Henderson, Nevada, where the primary effect was felt at a distance of up to 2,910 feet. Properties that are only 100 feet, rather than 2,910 feet, from the nearest church experience price premiums of 3.1\%. Bielefeld et al. (2006) observed price increases of $5.1 \%$ for residential properties in Marion County, Indiana, if they were located within a radius of one mile of at least four religious nonprofits. In Cleveland, Ohio, Ottensmann (2000) noted for census tracts with, or close to, a building of the Catholic diocese higher mean values of owner-occupied housing by $6.4 \%$. One reason for the divergent results of different studies may lie in the different levels of religiosity of the local population². The findings of Do, Wilbur, and Short (1994), which differ from other studies, could also be explained by methodological shortcomings of their study (for details, see Carroll, Clauretie, and

\footnotetext{
${ }^{1}$ However, over the past decades studies on the effects of externalities have commonly relied on the hedonic pricing technique. The impact on residential property prices has in recent years been analyzed using the hedonic framework, e.g., for air noise (e.g., Cohen and Coughlin 2009; McMillen 2004), road noise (e.g., Wilhelmsson 2000), rail noise (e.g., Clark 2006), (air) pollution (e.g., Decker, Nielsen, and Sindt 2005; Kim, Phipps, and Anselin 2003), rail transit stations (Bowes and Ihlanfeldt 2001), built heritage (e.g., Ahlfeldt and Maennig 2010) and school attributes (e.g., Clark and Herrin 2000).

${ }^{2}$ For a comparison of the proportion of regular churchgoers in U.S. states, cf. Newport (2010).
} 
Jensen (1996)). The authors are not aware of studies on the externalities of places of worship other than churches.

Hamburg today is a cosmopolitan metropolis, where followers of all five world religions have settled and built their places of worship. Churches dating back to two construction periods characterize the cityscape of Hamburg. On the one hand, there are a large number of churches from the late 19th century and early 20th century, reflecting the quick economic development of the port city. Accordingly, four of the fifteen tallest churches in the world are located in Hamburg. On the other hand, the two post-war decades between 1950 and 1970 resulted in a number of churches being built in the city. Today, however, it is mostly Lutheran communities that now experience difficulty in paying the operating costs for their churches from their community budgets. This has to do with the high number of people leaving the Lutheran church in recent years and decades, resulting in lower revenue from the church tax, as well as with the increase in energy and maintenance costs of church buildings (Konerding 2007). Consequently, as many as eleven Lutheran churches have been ${ }^{3}$ deconsecrated and then taken over by other denominations, rededicated or demolished (Ulrich 2010a). Numerous church buildings will likely meet the same fate in coming years (Benedict 2007).

After the Christians, Jews have lived the longest in Hamburg. The first arrived at the end of the 16th century (Bauche 1991). During Nazi rule, all synagogues in Hamburg were vandalized and subsequently rededicated, torn down or destroyed in the war. In 1960, the re-constituted Jewish community opened a new - and to date, the only - synagogue in Hamburg. After the Jews came the Buddhists, who founded their first association in 1906 (den Hoet 2006). Today there are six temples in Hamburg, where followers of the different Buddhist schools congregate. The first mosque in Hamburg was built in 1957, followed by many others over the following decades. Of the more than fifty mosques in Hamburg, during the study period only three had a dome and/or minarets that clearly

\footnotetext{
${ }^{3}$ Particularly the buildings of the two post-war decades constructed with concrete and its new structural possibilities show a high structural sensitivity (Konerding 2007), which necessitates high maintenance costs over the short and medium term.
} 
identified them as mosques to the outside world. Most mosques in Hamburg are housed in former commercial facilities or warehouses. The muezzin's call cannot be heard outside the Hamburg mosques. The last of the five world religions to settle in Hamburg were the Hindus in 1969 (Ulrich 2010a). They have set up two temples in former commercial facilities.

This study examines three current issues regarding the externalities of places of worship, which, to the authors' knowledge, have not been studied in the literature yet:

1) Against the background of the current political and social debate on the building of new minarets and the public call of the muezzin, the answer to the question whether mosques affect prices of adjacent residential properties differently than the places of worship of other religions could provide new stimulus for the debate.

2) In recent years, a number of churches have had to be closed down due to declining congregations. In light of the fact that more communities will have to abandon their church buildings in coming years (Benedict 2007), the question whether the externalities of buildings used for worship have different effects than deconsecrated church buildings was addressed. The answer to this question might be of useful help in deciding whether to tear down or rededicate a former church building.

3) Third, the question whether church bells affect the prices of residential properties was examined. The results can form the basis of a solution for some of the disputes being fought in court over bell ringing in residential areas.

Section 2 describes the data on which the study is based. Section 3 provides a description of the hedonic models used. The results are presented in Section 4. A summary and conclusion are provided in Section 5. 


\section{Data}

Housing price studies widely rely on sales prices for single- and two-family homes. This paper departs from this approach by using prices of condominiums, which make up the largest share of transactions involving residential properties in Hamburg (Committee of Valuation Experts in Hamburg 2009) and by using listing prices instead of sales prices. ${ }^{4}$ Using list prices may cause problems if the difference between the offer and transaction price is correlated with a condominium's physical characteristic or groups of characteristics.

Knight (2002) as well as Merlo and Ortalo-Magné (2004) show that the difference between offer and transaction prices is greater the longer a property is on the market. If we observed a correlation between time on market and distance to the closest place of worship, an unsystematic variance of the difference between listing and sales prices in relation to the distance to the closest place of worship would, thus, be doubtful. Here the Pearson correlation coefficient for time on market and distance to next place of worship, however, is small (0.015) and insignificant at conventional levels. ${ }^{5}$ For the condominium market in Hamburg, where the average differential between listing and transaction prices is approx. $8 \%$, no systematic variance of this difference for properties of different age, size or price category has been observed. ${ }^{6}$ Since this paper uses semi-logarithmic forms, which reflect relative - and not absolute - changes in property prices for an additional unit of a characteristic, the offer prices should yield unbiased coefficients.

The study area comprises the entire city of Hamburg, which has an area of 755.2 $\mathrm{km}^{2}$ and at the end of the study period a population of 1.767 million (March 31,

${ }^{4}$ In fact, in Germany a Committee of Valuation Experts that collects sales prices of housing units is located in every county. But in practice strict data protection regulations and high fees make it difficult to get access to detailed datasets of actual sales prices containing information on property's addresses.

${ }^{5}$ Grether and Mieszkowski (1974) also note that it is reasonable to assume that missing information on property characteristics, which may be connected to the use of offer data, does not give rise to a systematic bias of coefficients.

${ }^{6}$ Unpublished study of F+B GmbH from the year 2002. To the authors' knowledge, there have not been any further studies on the influence that property characteristics or the location of a property have on the difference between offer and transaction prices. 
2008). Hamburg is the second largest city in Germany, both in terms of its area and population. The primary source of data for this study is a dataset supplied by $\mathrm{F}+\mathrm{B} \mathrm{GmbH}$ that contains 4,832 listing prices for condominiums in Hamburg that were put up for sale on Internet portals between April 1, 2002 and March 31, 2008. All datasets contain information on the year of construction, size of the condominium, listing price and date, time on market, the complete address of the property as well as information on the characteristics of the condominium. Using a directory supplied by the Hamburg Office for Urban Development and the Environment (BSU), each address was allocated to one of the 938 statistical districts of Hamburg. A statistical district is the smallest statistical unit for which the Statistics Office of Hamburg collects demographic and socioeconomic population data. ${ }^{7}$ In addition, GIS was used to calculate distances between properties and public infrastructure (such as train stations, schools, kindergartens and shopping), bodies of water, green spaces and jobs. Employing small-scale datasets on the noise pollution caused by road, air and rail traffic supplied by the $\mathrm{BSU}$, property-specific noise pollution levels in $\mathrm{dB}(\mathrm{A})$ were determined.

Data on the addresses, religious affiliations and heights of Hamburg places of worship were collected in numerous sources. Using GIS, we geo-coded the locations of places of worship, assigned to each condominium the nearest place of worship and measured the distance between the two. Also, the floor space of each place of worship was estimated by means of aerial photographs. In addition, all church communities in Hamburg were contacted to determine whether or not a church has bells. For each church with bells, information was collected on whether they are used to mark the time (hourly, half-hourly or every fifteen minutes) and whether the marking of time of the church clock is turned off at night. $^{8}$

\footnotetext{
${ }^{7}$ All population data refer to the year in which the property was offered for sale most recently. The information regarding average income, however, was available only for 1995.

${ }^{8}$ For descriptive statistics of POW indicators see Table 3 and Table 4 in the appendix.
} 


\section{Empirical Methodology}

\section{Choice of functional form}

The choice of the proper parametric form of the hedonic regression equation is the subject of several publications (e.g., Bartik 1987; Cassell and Mendelsohn 1985; Cropper, Deck, and McConnell 1988; Halvorsen and Pollakowski 1981). However, since their advantage of allowing for non-linearity effects as well as intuitive interpretation of coefficients housing studies commonly rely on semilogarithmic functional forms. In recent years, authors have tended to use flexible forms such as the Box-Cox transformation (Box and Cox 1964). But, so far, the literature has not overcome the problems of implementing flexible functional forms in the presence of spatial dependence (Kim, Phipps, and Anselin 2003). As the models described below consider spatial-lag terms, this paper relies on semilogarithmic functional forms.

\section{Spatial dependence}

By introducing a spatial lag term (AUTOREG) it is assumed that listing prices also depend on the prices of the properties previously put up for sale in the neighborhood (Ahlfeldt and Maennig 2010). Owing to the nature of listing prices, which are generally guided by neighboring property prices, the spatial lag model is favored over the spatial error model, which assumes that spatial autocorrelation emerges from omitted variables that follow a spatial pattern (Kim, Phipps, and Anselin 2003). For condominium $i$ the value of the lag term is equivalent to the prices weighted by $w_{i j}=\left(1 / d_{i j}\right) / \Sigma_{j} 1 / d_{i j}$ of the surrounding $j$ summed-up apartments, when $1 / d_{i j}$ is the reciprocal distance between the condominiums $i$ and $j$ (Can and Megbolugbe 1997): ${ }^{9}$

${ }^{9}$ Can and Megbolugbe (1997) consider properties within a radius of 3 kilometers if the surrounding properties were sold in the previous six months. However, their study area covers a large-area suburban county in the metropolitan region of Miami. Regarding the small-scale housing market in Hamburg, it is reasonable to assume that the offer price of a condominium is affected only by prices of properties that are located in the immediate vicinity. However, AUTOREG was computed using various critical distances $(0.5,0.75,1.0,1.5,2.0,3.0,4.0,5.0,7.5$ 


$$
\operatorname{AUTOREG}_{i}=\sum_{j} \frac{\left(1 / d_{i j}\right)}{\sum_{j} 1 / d_{i j}} P_{j, t-m}, m=1, \ldots, 12 ; j=1, \ldots, N ; d_{i j} \leq 1 \mathrm{~km}
$$

\section{Model 1}

All models employ hedonic approaches that control for property, neighborhood, accessibility and noise indicators. Furthermore, Model 1 takes into account the proximity to POWs measured by a potentiality variable and can be written as:

$$
\begin{aligned}
\ln (P) & =\alpha+\beta \text { PROP }+\gamma \text { NEIGH }+\delta \text { ACCESS }+\eta \text { NOISE_VIS _ DIS }+\theta \text { AUTOREG } \\
& +\lambda \text { TREND }+\mu \text { POW_POTENTIALITY }+\varepsilon,
\end{aligned}
$$

where $\alpha, \beta, \gamma, \delta, \eta, \theta, \lambda$ and $\mu$ are the coefficients to be estimated and $\varepsilon$ is an error term. Property characteristics are captured by the vector PROP that includes information regarding age and size - which are considered in both linear form and with an additional quadratic term (e.g., Rickman 2009) - as well as dummy variables for the property's physical attributes..$^{10} \mathrm{NEIGH}$ is a vector of neighborhood characteristics, consisting of the proportion of those aged 65 and older (ELDERLYPOP), the average income (INCOME), the proportion of foreign population (FOREIGNPOP) as well as the number of social housing units per 1,000 inhabitants (SOCHOUSE). Descriptive statistics of the variables included in the final model specifications are listed in Table 1.

and $10.0 \mathrm{~km}$ ) and the best fit of the model was found when considering properties within a radius of $1 \mathrm{~km}$. In contrast to Can and Megbolugbe (1997), who take into account surrounding properties if they were sold in the previous six months, given the relatively low volatility of the condominium market in Hamburg during the study period, it is reasonable to include properties in the neighborhood that were offered for sale within the previous 12 months.

${ }^{10}$ In selecting the property variables, we widely follow Sirmans, Macpherson, and Zietz (2005) as well as Wilhelmsson (2000), who evaluated the control variables most commonly used in hedonic studies. 
Table 1 Variable Names, Definitions and Summary Statistics

\begin{tabular}{|c|c|c|c|}
\hline Variable & Definition & Mean & Std. dev. \\
\hline \multicolumn{4}{|l|}{ Dependent variable } \\
\hline PRICE & Last asking price of property & 193,897 & 177,747 \\
\hline \multicolumn{4}{|l|}{ Property } \\
\hline SIZE & Living area in square meters & 81.78 & 47.10 \\
\hline AGE & Age of property in years & 39.41 & 35.25 \\
\hline ROOMS & Number of rooms & 2.79 & 1.73 \\
\hline GARAGE & 1 if property has a garage, 0 otherwise & 0.52 & 0.50 \\
\hline BALCONY & 1 if property has a balcony, 0 otherwise & 0.82 & 0.38 \\
\hline TERRACE & 1 if property has a terrace, 0 otherwise & 0.77 & 0.42 \\
\hline KITCHEN & 1 if property has a built-in kitchen, 0 otherwise & 0.65 & 0.48 \\
\hline POOL & 1 if property has a pool, 0 otherwise & 0.03 & 0.16 \\
\hline FIREPLACE & 1 if property has a fireplace, 0 otherwise & 0.04 & 0.20 \\
\hline GOODCOND & 1 if property is in good condition, 0 otherwise & 0.13 & 0.34 \\
\hline BADCOND & 1 if property is in bad condition, 0 otherwise & 0.06 & 0.24 \\
\hline \multicolumn{4}{|l|}{ Neighborhood } \\
\hline ELDERLYPOP & $\begin{array}{l}\text { Proportion of population in statistical district that is } 65 \\
\text { years or older }\end{array}$ & 18.93 & 6.73 \\
\hline INCOME & $\begin{array}{l}\text { Mean income of population in statistical district (in } \\
1,000 € \text { ) }\end{array}$ & 34.80 & 15.18 \\
\hline FOREIGNPOP & Proportion of foreign population in statistical district & 13.06 & 6.64 \\
\hline SOCHOUSE & $\begin{array}{l}\text { Number of social housing units per } 1,000 \text { inhabitants in } \\
\text { statistical district }\end{array}$ & 40.65 & 62.27 \\
\hline \multicolumn{4}{|c|}{ (5) } \\
\hline DIST_CENT & $\begin{array}{l}\text { Distance to next sub center according to zoning plan (in } \\
\text { kilometers) }\end{array}$ & 1.16 & 0.82 \\
\hline EMPGRAV & $\begin{array}{l}\text { District proximity to employment (measured by a } \\
\text { gravity variable) }\end{array}$ & 145,867 & 43,925 \\
\hline DIST_STAT & Distance to next metro station (in kilometers) & 0.78 & 0.54 \\
\hline DIST_WATER & $\begin{array}{l}\text { Distance to closest of the bodies of water Elbe and } \\
\text { Binnen-/Aussenalster (in kilometers) }\end{array}$ & 4.68 & 3.67 \\
\hline DIST_PARK & $\begin{array}{l}\text { Distance to next park, forest or nature protection area } \\
\text { (in kilometers) }\end{array}$ & 0.69 & 0.51 \\
\hline DIST_SCH & Distance to next school (in kilometers) & 0.40 & 0.22 \\
\hline \multicolumn{4}{|c|}{ Noise exposure / visual intrusions } \\
\hline WIDEROAD & $\begin{array}{l}1 \text { if property is located on a wide road (with at least two } \\
\text { lanes per driving direction), } 0 \text { otherwise }\end{array}$ & 0.08 & 0.27 \\
\hline NOISE_ROAD & Road noise in $\mathrm{dB}(\mathrm{A})$ as measured by a $\mathrm{L}_{\mathrm{DEN}}$ index & 56.67 & 11.69 \\
\hline NOISE_AIR & $\begin{array}{l}\text { Air noise in } \mathrm{dB}(\mathrm{A}) \text { as measured by a } \mathrm{L}_{\mathrm{DEN}} \text { index if property } \\
\text { is located within noise protection zone } 2(\geq 67 \mathrm{~dB}(\mathrm{~A})) \\
\text { or } 3(\geq 62 \mathrm{~dB}(\mathrm{~A})) \text { around Hamburg airport, } 0 \text { otherwise }\end{array}$ & 2.19 & 10.95 \\
\hline NOISE_RAIL & $\begin{array}{l}\text { Rail noise in } \mathrm{dB}(\mathrm{A}) \text { as measured by a } \mathrm{L}_{\mathrm{DEN}} \text { index if } \\
\text { property is located in the vicinity of rail tracks, } 0 \\
\text { otherwise }\end{array}$ & 9.20 & 20.78 \\
\hline DIST_IND & Distance to next industrial area (in kilometers) & 0.55 & 0.46 \\
\hline
\end{tabular}


Table 1 (Continued)

\begin{tabular}{|c|c|c|c|}
\hline Variable & Definition & Mean & Std. dev \\
\hline \multicolumn{4}{|l|}{ Place of worship } \\
\hline POW_POTENTIALITY & POW potentiality variable as defined in equation (4) & 196.01 & 228.48 \\
\hline DIST_POW_100 & 1 if distance to next POW $\leq 100 \mathrm{~m}, 0$ otherwise & 0.05 & 0.21 \\
\hline DIST_POW_100_200 & $\begin{array}{l}1 \text { if distance to next POW }>100 \mathrm{~m} \text { and } \leq 200 \mathrm{~m}, 0 \\
\text { otherwise }\end{array}$ & 0.14 & 0.35 \\
\hline DIST_POW_200_400 & $\begin{array}{l}1 \text { if distance to next POW }>200 \mathrm{~m} \text { and } \leq 400 \mathrm{~m}, 0 \\
\text { otherwise }\end{array}$ & 0.35 & 0.48 \\
\hline DIST_POW_400_600 & $\begin{array}{l}1 \text { if distance to next POW }>400 \mathrm{~m} \text { and } \leq 600 \mathrm{~m}, 0 \\
\text { otherwise }\end{array}$ & 0.24 & 0.43 \\
\hline DIST_POW_600_1000 & $\begin{array}{l}1 \text { if distance to next POW }>600 \mathrm{~m} \text { and } \leq 1,000 \mathrm{~m}, 0 \\
\text { otherwise }\end{array}$ & 0.18 & 0.39 \\
\hline MOSOQUE & 1 if next POW is a mosque, 0 otherwise & 0.04 & 0.19 \\
\hline DECON & 1 if next POW is a deconsecrated church, 0 otherwise & 0.05 & 0.21 \\
\hline CHIME_DAY_ & Index of chime during day as defined in equation (8) & 0.00063 & 0.00920 \\
\hline CHIME_NIGHT_ & Index of chime during day as defined in equation (9) & 0.00029 & 0.00741 \\
\hline POTENTIALITY & & & \\
\hline
\end{tabular}

Access to jobs is measured by a gravity variable (Bowes and Ihlanfeldt 2001) that weights the number of jobs located in the 103 districts of Hamburg and the 307 surrounding communities in the metropolitan region of Hamburg each with their reciprocal distance to the city district where a condominium is located. ${ }^{11}$ To measure the access to public transport network the distance to the next railway station (DIST_STAT) was included - which is considered in both linear form and with an additional quadratic term (Agostini and Palmucci 2008). Proximity to shopping and recreation facilities has been captured by the distance to (sub-) centers (DIST_CENT) according to the zoning plan of Hamburg (BSU 2003) as well as the distance from the closest green space (DIST_PARK) and from the nearest bodies of water (DIST_WATER). ${ }^{12}$ Since schools and kindergartens are often

$11 \quad \operatorname{EMPGRAV}_{i}=\sum_{j} \frac{\mathrm{Emp}_{j}}{d_{i j}} \quad, d_{i i}=\frac{1}{3} \sqrt{\frac{\text { area }_{i}}{\Pi}}$

where Emp represents all jobs subject to social insurance in a city district or in one of the surrounding communities. $j$ stands for all city districts and communities other than $i$, and $d_{i j}$ is the distance between the centroids of $i$ and $j$. Since some of the city districts cover relatively large areas, a district-internal distance measure $d_{i i}$ is employed (e.g., Crafts 2005). In order to avoid overestimation of $E m p_{j}$ and/or $E m p_{i}, d_{i j}$ and/or $d_{i j}$ was not allowed to take on values smaller than 1 . The regression coefficient of the gravity variable calculated from the graded weights shows a higher $t$-value than the coefficient of the variable calculated from non-graded weights.

${ }^{12}$ All distance variables are stated as straight-line distances. 
located near places of worship, the models also capture the distance to such educational establishments. ${ }^{13}$ ACCESS is thus a vector to map the previously discussed accessibility indicators.

NOISE_VIS_DIS is a vector that, in addition to noise pollution in the entry and exit lanes of the Hamburg airport (NOISE_AIR), also takes into account noise and visual nuisances stemming from road traffic (NOISE_ROAD_SQ, WIDEROAD) as well as railway noise near railway tracks (NOISE_RAIL) and that captures the distance to industrial sites (DIST_IND). The vector TREND stands for a set of dummy variables that capture the most recent year and the most recent season in which a property was offered for sale.

POW ${ }_{-}$POTENTIALITY $Y_{i}=\sum_{j} A_{j} e^{-z d_{i j}}$

First, the spatial extent of the effect of places of worship is examined using a potentiality variable, which is estimated as an exponential spatial weight function (Ahlfeldt and Maennig 2010). For condo i POW_POTENTIALITY corresponds to the sum of the floor space $A$ weighted with the term $\exp \left(-z d_{i j}\right)$ of all places of worship $j$ in Hamburg. $d_{i j}$ is the distance between property $i$ and the place of worship $j$, and $z$ is a spatial weight used to weight the floor space ${ }^{14}$ of the places of worship in relation to their distance from property $i$. By calculating POW_POTENTIALITY for different values of $z$ (0.1 to 15) the best fit is found for $z=$ 5 (cf. also Fig. 1). ${ }^{15}$ The spatial effect of places of worship in Hamburg is thus

${ }^{13}$ The best fitting model was retrieved when considering the distance to the closest school both in linear and quadratic form. The influence of the distance to the nearest kindergarten was insignificant for all tested terms, which is why this indicator has been excluded from the final model specifications.

${ }^{14}$ In preliminary estimations, not only the floor space but also the height of places of worship was tested. Also, the volume of places of worship was approximated using various terms. However, the height and/or volume of places of worship was insignificant for all tested terms, which is why these indicators were excluded from the final models. One reason for the insignificant findings could be found in the deficient data quality of height information. For many buildings, it was impossible to research the height, which then had to be estimated from photographs of the properties. Another reason for the insignificant coefficients could lie in the variety of building structures of places of worship, which probably can be approximated only insufficiently using uniform terms.

${ }^{15}$ POW_POTENTIALITY was tested with $z=0.1,0.25,0.5,0.75,1.0,1.5,2.0,3.0,4.0,5.0,6.0,7.0,8.0$, 9.0, $10.0,15.0$. 
halved approx. every $140 \mathrm{~m}$ and is limited to a radius of approx. $1 \mathrm{~km} .^{16}$ This is also plausible when compared to the findings of Ahlfeldt and Maennig (2010), who, using potentiality variables, have observed a spatial effect of built heritage at distances of up to $600 \mathrm{~m}$. Since places of worship are normally taller than heritage-listed properties, they may also have a stronger spatial effect on the prices of surrounding residential properties.

Fig. 1 Selection of Estimated Spatial Weight Functions for Different $z(0.1-15.0)$

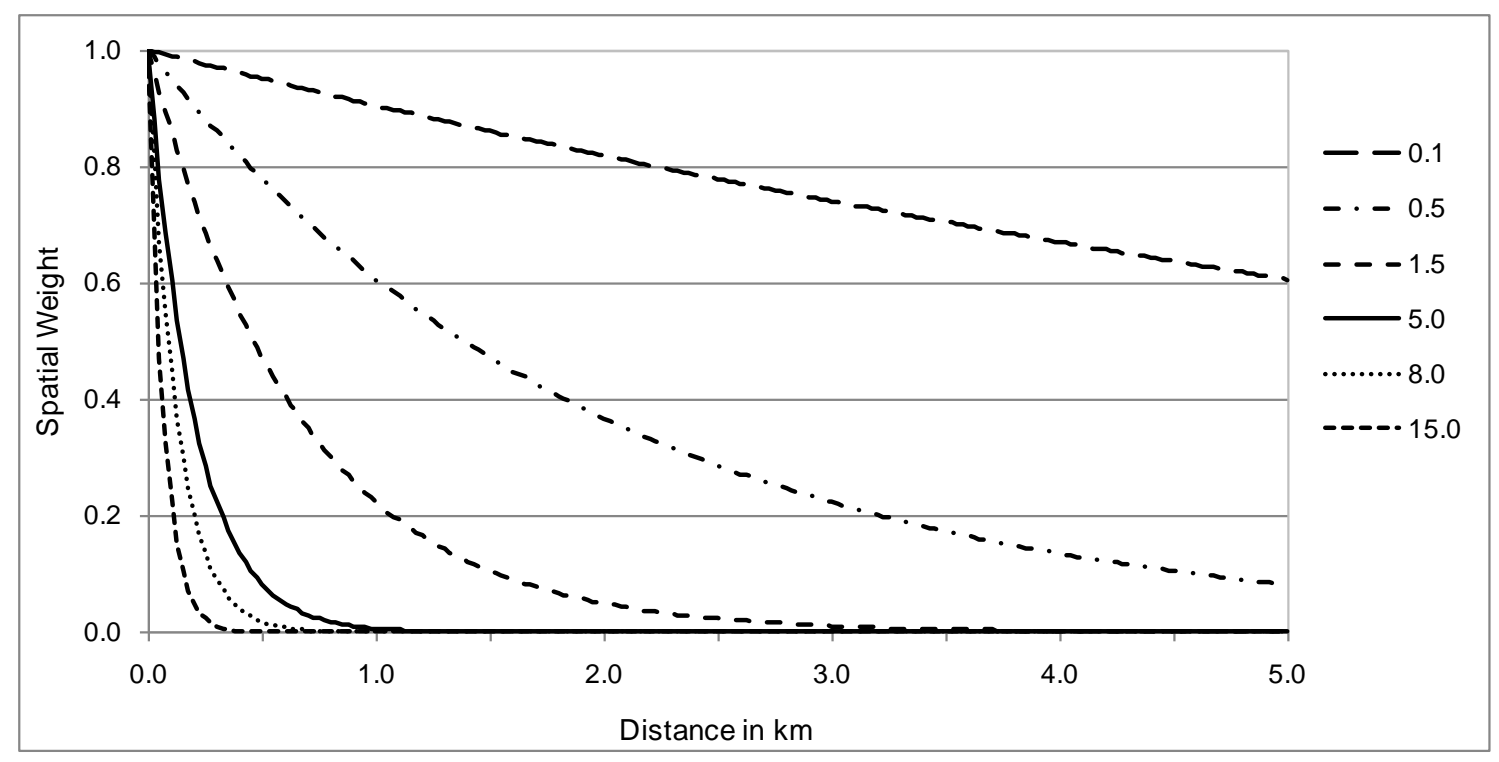

Model 2

Taking into account the findings gained from Model 1, in Model 2 the influence of places of worship is examined by means of a conventional approach. That is, by introducing a set of dummy variables that capture distance contours around POWs. Model 2 can thus be written as follows:

$$
\begin{aligned}
\ln (P) & =\alpha+\beta P R O P+\gamma \text { NEIGH }+\delta \text { ACCESS }+\eta N O I S E_{-} \text {VIS _ DIS }+\theta \text { AUTOREG } \\
& +\lambda \text { TREND }+\sigma \text { DIST_POW }+\varepsilon,
\end{aligned}
$$

\footnotetext{
${ }^{16}$ For $d_{i j}=1.0$, the weight $\exp \left(-5 d_{i j}\right)=0.0067$
} 
where $\sigma$ is a vector of the coefficients to be estimated. DIST_POW is a vector of five dummy variables that each take on the value of 1 if a property is located at a distance of up to $100 \mathrm{~m}$ (DIST_POW_100), more than $100 \mathrm{~m}$ and up to $200 \mathrm{~m}$ (DIST_POW_100_200), more than 200m and up to 400m (DIST_POW_200_400), more than 400m and up to 600m (DIST_POW_400_600) or more than 600m and up to 1,000m (DIST_POW_600_1000) from the next POW; otherwise the value is $0 .{ }^{17}$ Accounting for the findings from Model $1,1,000 \mathrm{~m}$ is defined as the maximum cutoff, using properties at distances of more than $1,000 \mathrm{~m}$ to the next POW as the reference group. The use of dummy variables has the advantage that their coefficients, in contrast to those of spatial weight terms, are easy to interpret and present an intuitive measure of the influence of POWs on residential property prices.

\section{Model 3}

In Model 3, we first analyze whether the externalities of mosques are different than those of other places of worship. In answering this question, we hope to obtain new input for the social debate on the construction of minarets and/or the public muezzin's call. Secondly, it is examined whether the externalities of deconsecrated churches differ from those of buildings used as places of worship. Taking into account the uncertain future of many - primarily Lutheran - churches, answering this question may supply impulses for the debate on the future use of former places of worship.

DIST_POW is additionally interacted with the variables MOSOUE and DECON. Thus, Model 3 is as follows:

$$
\begin{aligned}
\ln (P) & =\alpha+\beta P R O P+\gamma \text { NEIGH }+\delta \text { ACCESS }+\eta \text { NOISE_VIS _ DIS }+\theta \text { AUTOREG } \\
& +\lambda \text { TREND }+\sigma \text { DIST_POW }+\varphi \text { DIST_POW } \times \text { MOSQUE } \\
& +\psi \text { DIST_POW } \times \text { DECON }+\varepsilon
\end{aligned}
$$

\footnotetext{
${ }^{17}$ All other terms in equation (5) have the meanings previously described for model 1.
} 
where $\varphi$ and $\psi$ are the coefficients to be estimated. MOSQUE and/or DECON take on the value of 1 if the next POW is a mosque and/or a deconsecrated church; otherwise the value is $0 .{ }^{18}$ For example, the interactive variable DIST_POW_100_200 x MOSOUE takes on the value of 1 if the next POW is a mosque that is located within a radius of $100 \mathrm{~m}$ to $200 \mathrm{~m}$ from the property; otherwise the value is 0 . The coefficient of the interactive variable DIST_POW_100_200 x MOSOUE thus indicates, for example, the price differential of properties within a radius of $100 \mathrm{~m}$ to $200 \mathrm{~m}$ around mosques compared to properties that are located at distances between $100 \mathrm{~m}$ and $200 \mathrm{~m}$ around POWs of other religions that were not deconsecrated.

\section{Model 4}

Finally, in Model 4, the extent to which residential property prices are influenced by the bell ringing of nearby churches is examined. First, a distinction must be made between liturgical bell ringing - e.g., on church holidays, to mark services and official church acts such as baptisms, weddings or funerals - and the secular marking of time of the church clock at quarterly, half-hourly or hourly intervals. In preliminary analyses, various terms were included to test whether it makes a difference that adjacent church spires have bells or not. However, the variables did not yield any significant results, which may primarily be due to the fact that bells are rung with varying frequency and intensity in each community. However, data on the frequency and intensity of liturgical bell ringing in the various communities was not available, because the variety of ringing could be quantified - if at all - only with disproportionate effort for the entire metropolitan area of Hamburg. Besides, the regular marking of time, which is more frequent than liturgical bell ringing and can be heard even at nighttime in many communities, probably creates greater noise pollution anyway. Therefore, for each church in Hamburg it is considered whether the church marks the time and if so, at what

\footnotetext{
${ }^{18}$ Deconsecrated churches are properties that were not used as places of worship anymore during the study period but whose buildings still existed.
} 
frequency and at what time of day this occurs. Model 4 can thus be written as follows:

$$
\begin{aligned}
\ln (P) & =\alpha+\beta \text { PROP }+\gamma \text { NEIGH }+\delta \text { ACCESS }+\eta \text { NOISE }_{-} \text {VIS _ DIS }+\theta \text { AUTOREG } \\
& +\lambda \text { TREND }+\sigma \text { DIST_POW }+\varphi \text { DIST_POW } \times \text { MOSQUE } \\
& +\psi \text { DIST_POW } \times \text { DECON }+\omega \text { CHIME }+\varepsilon,
\end{aligned}
$$

where $\omega$ is a vector of the coefficients to be estimated. CHIME is a vector of the two potentiality variables CHIME_DAY_POTENTIALITY and CHIME_NIGHT_POTENTIALITY, which, using exponential spatial weight functions, account for the marking of time of all church clock towers in Hamburg in relation to frequency, time of day and distance to the respective condominium. The variable CHIME_DAY_INDEX takes on the value 4 for church $j$ if time is marked at quarterly intervals, or the value 2 if time is marked every half-hour, or the value 1 if time is marked hourly; otherwise the value is 0 .

$$
\text { CHIME_DAY_POTENTIALITY } Y_{i}=\sum_{j} C H I M E \_D A Y \_I N D E X_{j} e^{-z d_{i j}}
$$

For condominium i CHIME_DAY_POTENTIALITY corresponds to the sum of the CHIME_DAY_INDEX values of all Hamburg churches $j$ weighted with the term $\exp \left(-z d_{i j}\right) \cdot d_{i j}$ is the distance between property $i$ and church $j$, and $z$ is a spatial weight used to weight the values of CHIME_DAY_INDEX in relation to $d_{i j}$. For the calculation of CHIME_DAY_POTENTIALITY $z$ is considered to take on values from 15 to 100 (see also Fig. 2). ${ }^{19}$

${ }^{19}$ CHIME_DAY_POTENTIALITY and CHIME_NIGHT_POTENTIALITY were tested each with $\mathrm{z}=15.0$, $16.0, \overline{1} 7.0, \overline{1} 8.0,20.0,22.5,25.0,30.0,35.0,40.0,50.0,60.0,70.0,80.0,90.0,100.0$. 
Fig. 2 Selection of Estimated Spatial Weight Functions for Different z (15.0-100.0)

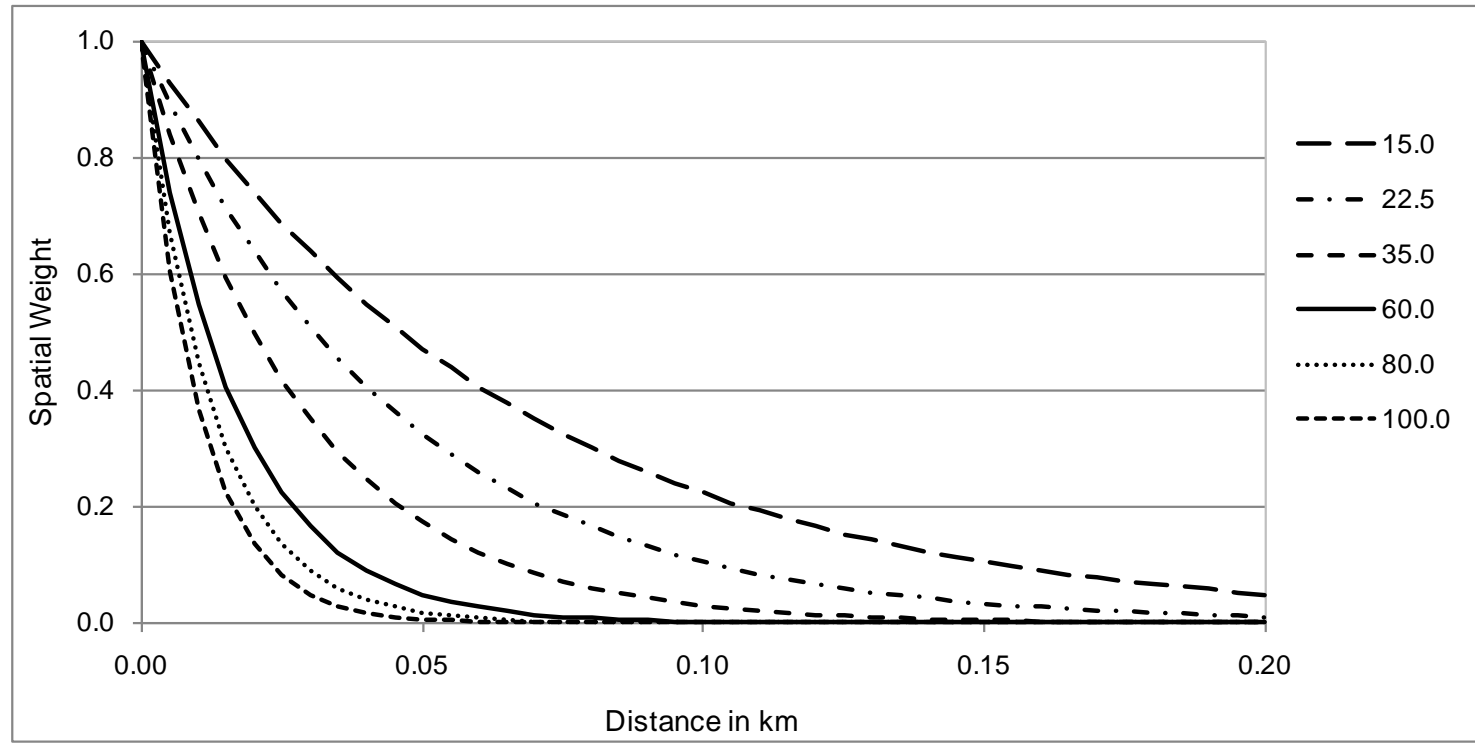

CHIME_NIGHT_POTENTIALITY $=\sum_{j} C H I M E \_N I G H T \_I N D E X_{j} e^{-z d_{i j}}$

The calculation of the variable CHIME_NIGHT_POTENTIALITY follows the same principle. For church $j$ CHIME_NIGHT_INDEX is equal to the value of CHIME_DAY_INDEX when the marking of time occurs also at night (at least from 12:00 AM to 6:00 AM); otherwise the value is 0 .

\section{Results}

About $87.2 \%$ of the variance of listing prices can be explained by the hedonic models used (Table 2). ${ }^{20}$ This is an average value when compared to other hedonic housing price studies. Since White's test rejects homoscedasticity for all models, the standard errors were corrected using White's Correction. All control variables have the expected signs and are predominantly highly significant, yielding values that are plausible also in terms of their amounts.

${ }^{20}$ If the models are specified without the spatial lag term, the adjusted $R^{2}$ value is reduced by approx. $1.0 \%$. 
Table 2 Results

\begin{tabular}{|c|c|c|c|c|}
\hline & Model 1 & Model 2 & Model 3 & Model 4 \\
\hline CONSTANT & $8.4549^{* * *}$ & $8.4323^{* * *}$ & $8.4384^{* * *}$ & $8.4445^{* * *}$ \\
\hline \multicolumn{5}{|l|}{ Property } \\
\hline SIZE & $0.0132^{* * *}$ & $0.0132^{* * *}$ & $0.0132^{* * *}$ & $0.0132^{* * *}$ \\
\hline SIZE_SO- & $-0.000009^{* * *}$ & $-0.000009^{* * *}$ & $-0.000009^{* * *}$ & $-0.000009^{* * *}$ \\
\hline AGE & $-0.0130^{* * *}$ & $-0.0129^{* * *}$ & $-0.0129^{* * *}$ & $-0.0130^{* * *}$ \\
\hline AGE_SO & $0.000098^{* * *}$ & $0.000097^{* * *}$ & $0.000098^{* * *}$ & $0.000098^{* * *}$ \\
\hline ROOMS & $0.0267^{* *}$ & $0.0268^{* *}$ & $0.0267^{* *}$ & $0.0265^{* *}$ \\
\hline GARAGE & $0.0328^{* * *}$ & $0.0334^{* * *}$ & $0.0334^{* * *}$ & $0.0347^{* * *}$ \\
\hline BALCONY & $0.0592^{* * *}$ & $0.0583^{* * *}$ & $0.0574^{* * *}$ & $0.0571^{* * *}$ \\
\hline TERRACE & $0.0396^{* * *}$ & $0.0395^{* * *}$ & $0.0401^{* * *}$ & $0.0399^{* * *}$ \\
\hline KITCHEN & $0.0409^{* * *}$ & $0.0411^{* * *}$ & $0.0414^{* * *}$ & $0.0421^{* * *}$ \\
\hline POOL & 0.0337 & 0.0357 & 0.0366 & 0.0366 \\
\hline FIREPLACE & 0.0111 & 0.0104 & 0.0104 & 0.0099 \\
\hline GOODCOND & $0.0503^{* * *}$ & $0.0507^{* * *}$ & $0.0504^{* * *}$ & $0.0504^{* * *}$ \\
\hline BADCOND & $-0.1052^{* * *}$ & $-0.1057^{* * *}$ & $-0.1047^{* * *}$ & $-0.1049^{* * *}$ \\
\hline \multicolumn{5}{|l|}{ Neighborhood } \\
\hline ELDERLYPOP & $-0.0033^{* * *}$ & $-0.0034^{* * *}$ & $-0.0034^{* * *}$ & $-0.0034^{* * *}$ \\
\hline INCOME & $0.0031^{* * *}$ & $0.0031^{* * *}$ & $0.0031^{* * *}$ & $0.0032^{* * *}$ \\
\hline FOREIGNPOP & $-0.0057^{* * *}$ & $-0.0056^{* * *}$ & $-0.0058^{* * *}$ & $-0.0057^{* * *}$ \\
\hline SOCHOUSE & $-0.0002^{* * *}$ & $-0.0002^{* * *}$ & $-0.0002^{* * *}$ & $-0.0002^{* * *}$ \\
\hline \multicolumn{5}{|l|}{ Access } \\
\hline DIST_CENT & $-0.0247^{* * *}$ & $-0.0245^{* * *}$ & $-0.0240^{* * *}$ & $-0.0242^{* * *}$ \\
\hline EMPGRAV & $0.000002^{* * *}$ & $0.000002^{* * *}$ & $0.000002^{* * *}$ & $0.000002^{* * *}$ \\
\hline DIST_STAT & $0.0374^{*}$ & $0.0394^{*}$ & $0.0395^{*}$ & $0.0343^{*}$ \\
\hline DIST_STAT_SO- & $-0.0211^{* *}$ & $-0.0215^{* *}$ & $-0.0216^{* *}$ & $-0.0195^{* * *}$ \\
\hline DIST_WATER & $-0.0077^{* * *}$ & $-0.0076^{* * *}$ & $-0.0077^{* * *}$ & $-0.0076^{* * *}$ \\
\hline DIST_PARK & $-0.0444^{* * *}$ & $-0.0444^{* * *}$ & $-0.0445^{* * *}$ & $-0.0446^{* * *}$ \\
\hline DIST_SCH & $0.1598^{* * *}$ & $0.1557^{* * *}$ & $0.1577^{* * *}$ & $0.1572^{* * *}$ \\
\hline DIST_SCH_SO & $-0.1367^{* * *}$ & $-0.1292^{* * *}$ & $-0.1290^{* * *}$ & $-0.1304^{* * *}$ \\
\hline \multicolumn{5}{|c|}{ Noise exposure / visual intrusions } \\
\hline WIDEROAD & $-0.0460^{* * *}$ & $-0.0461^{* * *}$ & $-0.0470^{* * *}$ & $-0.0468^{* * *}$ \\
\hline NOISE_ROAD_SO & $-0.000019^{* * *}$ & $-0.000020^{* * *}$ & $-0.000020^{* * *}$ & $-0.000020^{* * *}$ \\
\hline NOISE_AIR & $-0.0011^{* * *}$ & $-0.0011^{* * *}$ & $-0.0011^{* * *}$ & $-0.0011^{* * *}$ \\
\hline NOISE_RAIL & $-0.0011^{* * *}$ & $-0.0011^{* * *}$ & $-0.0011^{* * *}$ & $-0.0011^{* * *}$ \\
\hline DIST_IND & $0.0178^{*}$ & $0.0225^{* *}$ & $0.0237^{* *}$ & $0.0234^{* *}$ \\
\hline
\end{tabular}


Table 2 (continued)

Model 1

\begin{tabular}{l}
\hline Place of worship \\
POW_POTENTIALITY \\
DIST_POW_100 \\
DIST_POW_100_200 \\
DIST_POW_200_400 \\
DIST_POW_400_600 \\
DIST_POW_600_1000 \\
DIST_POW_100 x MOSOUE \\
DIST_POW_100_200 x MOSOUE \\
DIST_POW_200_400 x MOSOUE \\
DIST_POW_400_600 x MOSOUE \\
DIST_POW_600_1000 x MOSOUE \\
DIST_POW_100 x DECON \\
DIST_POW_100_200 x DECON \\
DIST_POW_200_400 x DECON \\
DIST_POW_400_600 x DECON \\
DIST_POW_600_1000 x DECON \\
CHIME_DAY_POTENTIALITY \\
CHIME_NIGHT_POTENTIALITY
\end{tabular}

Model 2 $0.000065^{* * *}$

\begin{tabular}{llc}
0.0381 & 0.0384 & 0.0466 \\
$0.0480^{* *}$ & $0.0470^{* *}$ & $0.0475^{* *}$ \\
0.0262 & 0.0254 & 0.0259 \\
0.0090 & 0.0084 & 0.0093 \\
0.0003 & 0.0019 & 0.0028 \\
& 0.0397 & 0.0292 \\
& 0.0383 & 0.0363 \\
& 0.0334 & 0.0325 \\
& -0.0209 & -0.0225 \\
& -0.0336 & -0.0334 \\
& -0.0279 & -0.0365 \\
& -0.0099 & -0.0094 \\
& 0.0059 & 0.0063 \\
& 0.0214 & 0.0217 \\
& -0.0966 & -0.0961 \\
& & 0.1992 \\
& & -1.6556 \\
\hline 4,832 & 4,832 & 4,832 \\
YES & YES & YES \\
YES & YES & YES \\
0.873 & 0.874 & 0.874 \\
0.872 & 0.872 & 0.872
\end{tabular}

\begin{tabular}{lcccc}
\hline Number of observations & 4,832 & 4,832 & 4,832 & 4,832 \\
White's Correction & YES & YES & YES & YES \\
Spatial lag term & YES & YES & YES & YES \\
$R^{2}$ & 0.873 & 0.873 & 0.874 & 0.874 \\
${\text { Adjusted } R^{2}}^{2}$ & 0.872 & 0.872 & 0.872 & 0.872 \\
\hline
\end{tabular}

Notes: The endogenous variable is the natural log of the last listing price of property. All models include yearly and seasonal dummy variables. ${ }^{*}$ indicates significance at the $10 \%$ level; ${ }^{* *}$ indicates significance at the $5 \%$ level; ${ }^{* * *}$ indicates significance at the $1 \%$ level.

\section{Control variables}

The coefficients estimated for SIZE and SIZE_SO show the expected positive, but less than proportional effect of property size on condominium prices. The estimates of $A G E$ and $A G E \_S O$ indicate a quadratic influence for the property's age, with the lowest prices for condominiums that are 66 years old. Regarding the other condominium's physical characteristics, only a generally bad condition of the property (BADCOND) has a negative effect on condominium prices. ${ }^{21}$ Among the neighborhood variables only the relationship between average income (INCOME) and condominium prices is positive. All other coefficients of

${ }^{21}$ The coefficients of dummy variables used in the semi-log form were transformed by $\left(e^{a}-1\right)$, where $a$ is the estimated coefficient (Halvorsen and Palmquist 1980). 
neighborhood indicators have negative signs. The coefficients of DIST_STAT and DIST_STAT_SO show that the highest prices for properties can be found at a distance of approx. $900 \mathrm{~m}$ from the next rail station. Also the estimates of DIST_SCH and DIST_SCH_SO indicate a quadratic relation between distance from next school and housing prices. Coefficients of all other variables that measure distance from local amenities have the expected negative signs. Furthermore, access to jobs, measured by EMPGRAV, is seen as positive. While condominiums located next to a major road (WIDEROAD) experience price reductions of $4.6 \%$, the coefficients of all traffic-noise indices (NOISE_ROAD_SQ, NOISE_AIR, NOISE_RAIL) are negative and statistically highly significant.

Impact of POWs

As mentioned above, tests with the potentiality variable POW_POTENTIALITY in Model 1 have shown that the spatial effect of places of worship is limited to around 1,000m. Model 2 now shows that the price premiums for the proximity to places of worship increase between $1,000 \mathrm{~m}$ and $100 \mathrm{~m}$ with declining distance, resulting in maximum premiums of $4.8 \%$ for locations between $100 \mathrm{~m}$ and $200 \mathrm{~m}$ from the nearest place of worship (DIST_POW_100_200). Compared to the property prices at a distance of more than $1,000 \mathrm{~m}$ from the nearest place of worship, however, only premiums at a distance of $100 \mathrm{~m}$ to $200 \mathrm{~m}$ are significant. This result is plausible insofar as $200 \mathrm{~m}$ also represents a plausible cutoff for a high visual perception of the buildings. In immediate proximity to places of worship, that is, at a distance of up to 100m (DIST_POW_100), price premiums are lower and not significantly different from residential property prices at a distance of more than 1,000m from the nearest place of worship. The lower premiums in close proximity to places of worship may result from noise pollution, for example, from community or cultural events, visitor traffic or church bell ringing. This topic will be further discussed when presenting the findings of Model 4. In summary, the estimated premiums near places of worship are comparable to previously reported premiums in the vicinity of churches that range from 3.1\% (Carroll, Clauretie, and Jensen 1996) to 6.4\% (Ottensmann 2000). Also, the estimated 
spatial extent of externalities of places of worship is comparable to the spatial effect of church buildings observed by Do, Wilbur, and Short (1994) and Ottensmann (2000). However, Carroll, Clauretie, and Jensen (1996) and Bielefeld et al. (2010) reported more far-reaching spatial effects.

In Model 3, the insignificant coefficients of the interactive vectors DIST_POW $\mathrm{x}$ MOSQUE and DIST_POW $\times$ DECON give rise to the conclusion that the condominium prices in Hamburg, either near mosques or in the vicinity of deconsecrated churches, do not differ significantly from property prices in the neighborhood of places of worship of other religions and/or in the vicinity of actively-used places of worship. Given the positive - albeit insignificant coefficients of the interactive terms DIST_POW_100 x MOSOUE, DIST_POW_100_200 x MOSQUE and DIST_POW_200_400 x MOSQUE, one could speculate that easy access to a place of worship matters more to Muslims than it does to believers of other religions. In fact, approx. 36\% of Hamburg Muslims attend a mosque regularly (Ulrich 2010b), while, for example, only around $12 \%$ of Catholics in Hamburg attend church mass regularly (Ulrich 2010a). The fact that prices of residential properties near rededicated churches are not statistically different from prices in the vicinity of actively-used places of worship leads to the conclusion that, seemingly, the visual amenities of churches are key to price premiums, rather than easy access to church services and/or community and cultural events.

In Model 4, the potentiality variables CHIME_DAY_POTENTIALITY and CHIME_NIGHT_POTENTIALITY are calculated for $z$ values from 15 to 100. For both variables the best fit is obtained for $z=60$ (see also Fig. 2). ${ }^{22}$ However, the coefficients of both variables are insignificant even for $z=60$. Therefore, an effect of bell ringing on the prices of nearby residential properties cannot be proved. At least with respect to bell ringing at night, price reductions in the immediate neighborhood would have been expected. A weakness of the model is certainly that the level of noise exposure from church bells depends on further factors that the model does not control for. Thus, the volume of the bells of different churches

\footnotetext{
${ }^{22}$ Accordingly, the spatial effect of bell ringing is reduced by half approx. every $12 \mathrm{~m}$ and is limited to a radius of approx. $80 \mathrm{~m}$ (for $d_{i j}=0.08$, the weight exp $\left(-60 d_{i j}\right)=0.0082$ ).
} 
can vary greatly. Many church towers still have steel bells from the post-war years. Their sound is rather shrill. By contrast, later cast steel bells and bronze bells tend to produce a warm sound. Furthermore, bells are suspended at different heights, which could result in different noise levels at the same distance from the nearest church tower. Although the model controls for the frequency and time of day of bell ringing as well as the distance from residential properties, the aforementioned constraints may lead to biased results. An interesting aspect is, however, that the coefficient of DIST_POW_100 rises by almost a percentage point compared to Model 3 and is now more or less equivalent to the coefficient of DIST_POW_100_200.DIST_POW_100 is now also significant at least at the $11 \%$ level. The lower price premiums reported for Models 2 and 3 in immediate proximity to places of worship, therefore, can largely be explained by the noise exposure to church bells even if the influence of the noise itself is not statistically significant.

\section{Conclusions}

Applying hedonic pricing techniques this study examines the impact of places of worship on residential property prices in Hamburg, Germany. Controlling for spatial dependence and employing potentiality variables places of worship are found to have positive external effects on neighboring condominium prices within a distance of approx. 1,000m. Compared to properties beyond this threshold, price premiums of $4.8 \%$ are obtained for condominiums at distances of $100 \mathrm{~m}$ to $200 \mathrm{~m}$ to the next place of worship. As a result of noise exposure, however, price premiums in immediate proximity to places of worship $(\leq 100 \mathrm{~m})$ are lower and not significantly different from property prices at a distance of more than $1,000 \mathrm{~m}$ from the nearest place of worship. Condominium prices in Hamburg, either near mosques or in the vicinity of deconsecrated churches, are not significantly different from prices in the neighborhood of places of worship of other religions and/or in the vicinity of actively-used places of worship. Thus, no price discounts for residential properties have been observed in the vicinity of mosques that would account for local residents feeling bothered by Islamic places of worship. The findings also imply that churches should be preserved as 
buildings, because they continue to have positive externalities on adjacent residential property prices even after they have been deconsecrated. The influence of church bell ringing on the prices of surrounding residential properties, however, could not be substantiated.

It should be noted, however, that the study was conducted in a metropolis known for its liberalism and open-mindedness. The findings may be different for conservative and/or rural regions. This warrants further research.

\section{Literature}

AGOSTINI, C. A. / PALMUCCI, G. A. (2008), The anticipated capitalisation effect of a new metro line on housing prices. Fiscal Studies 29(2), 233-256.

AHLFELDT, G. M. / MAENNIG, W. (2010), Substitutability and complementarity of urban amenities: External effects of built heritage in Berlin. Real Estate Economics 38(2), 285-323.

BARTIK, T. J. (1987), The estimation of demand parameters in hedonic price models. Journal of Political Economy 95(1), 81-88.

BAUCHE, U. (1991), Four hundred years of Jews in Hamburg: An exhibition of the Museum of Hamburg History from November 8, 1991 until March 29, 1992. Hamburg: Dölling \& Galitz (in German).

BENEDICT, H.-J. (2007), Viewing from steeple to steeple - A vision of the 1950s and their consequences. In: Hamburg Office for the Preservation of Historical Monuments (Ed.), Architecture of tomorrow. The postwar period churches of Hamburg (pp. 19-22). Hamburg: Dölling \& Galitz (in German).

BIELEFELD, W. / MAN, J. / McLAUGHLIN, W. / PAYTON, S. (2006), The location of nonprofit organizations influences residential housing prices: A study in Marion County, Indiana. Center for Urban Policy and the Environment, School of Public and Environmental Affairs, Indiana University-Purdue University Indianapolis. 
BOWES, D. R. / IHLANFELDT, K. R. (2001), Identifying the impacts of rail transit stations on residential property values. Journal of Urban Economics 50(1), 125.

BOX, G. E. P. / COX, D. R. (1964), An analysis of transformations. Journal of the Royal Statistical Society B 26(2), 211-252.

BSU. (2003), Centers: Central locations according to zoning plan and stock of local supply. Hamburg: Office for Urban Development and the Environment (in German).

CAN, A. / MEGBOLUGBE, I. (1997), Spatial dependence and house price index construction. The Journal of Real Estate Finance and Economics 14(1-2), 203-222.

CAROLL, T. M. / CLAURETIE, T. M. / JENSEN, J. (1996), Living next to godliness: Residential property values and churches. The Journal of Real Estate Finance and Economics 12(3), 319-330.

CASSEL, E. / MENDELSOHN, R. (1985), The choice of functional forms for hedonic price equations: Comment. Journal of Urban Economics 18(2), 135-142.

CLARK, D. E. (2006), Externality effects on residential property values: The example of noise disamenities. Growth and Change 37(3), 460-488.

CLARK, D. E. / HERRIN, W. E. (2000), The impact of public school attributes on home sale prices in California. Growth and Change 31(3), 385-407.

COHEN, J. P. / COUGHLIN, C. C. (2009), Changing noise levels and housing prices near the Atlanta airport. Growth and Change 40(2), 287-313.

COMMITTEE OF VALUATION EXPERTS IN HAMBURG (2009), Compilation of purchasing price data 2008. Hamburg: Committee of Valuation Experts in Hamburg (in German).

CRAFTS, N. (2005), Market potential in British regions, 1871-1931. Regional Studies 39(9): 1159-1166. 
CROPPER, M.L. / DECK, L. B. / McConnell, K. E. (1988), On the choice of functional form for hedonic price functions. The Review of Economics and Statistics 70(4), 668-675.

DECKER, C. S. / NIELSEN, D. A. / SINDT, R. P. (2005), Residential property values and community right-to-know laws: Has the toxics release inventory had an impact? Growth and Change 36(1), 113-133.

DEN HOET, M. (2006), One hundred years of Buddhism in Hamburg. The Buddhist Channel. http://www.buddhistchannel.tv/index.php?id=3,2803,0,0,1,0 (Accessed November 2010).

DO, A. O. / SHORT, J. L. / WILBUR, R. W. (1994), An empirical examination of the externalities of neighborhood churches on housing values. The Journal of Real Estate Finance and Economics 9(2), 127-136.

GRETHER, D.M. / MIESZKOWSKI, P. (1974), Determinants of real estate values. Journal of Urban Economics 1(2), 127-145.

HALVORSEN, R. / PALMOUUIST, R. (1980), The interpretation of dummy variables in semilogarithmic equations. American Economic Review 70(3), 474-475.

HALVORSEN, R. / POLLAKOWSKI, H. O. (1981), Choice of functional form for hedonic price equations. Journal of Urban Economics 10(1), 37-49.

ANSELIN, L. / KIM, C. W. / PHIPPS, T. T. (2003), Measuring the benefits of air quality improvement: A spatial hedonic approach. Journal of Environmental Economics and Management 45(1), 24-39.

KNIGHT, J. R. (2002), Listing price, time on market, and ultimate selling price: Causes and effects of listing price changes. Real Estate Economics 30(2), 213237.

KONERDING, V. (2007), Churches of the postwar period and preservation of historical monuments. In: Hamburg Office for the Preservation of Historical Monuments (Ed.), Architecture of tomorrow. The postwar period churches of Hamburg (pp. 30-32). Hamburg: Dölling \& Galitz (in German). 
LEE, M. R. / OUSEY, G. C. (2005), Institutional access, residential segregation, and urban Black homicide. Sociological Inquiry 75(1), 31-54.

MCMILLEN, D. P. (2004), Airport expansions and property values: The case of Chicago O'Hare airport. Journal of Urban Economics 55(3), 627-640.

MERLO, A. / ORTALO-MAGNÉ, F. (2004), Bargaining over residential real estate: Evidence from England. Journal of Urban Economics 56(2), 192-216.

NEWPORT, F. (2010), Mississippians go to church the most; Vermonters, least. GALLUP. http://www.gallup.com/poll/125999/Mississippians-Go-ChurchMost-Vermonters-Least.aspx (Accessed December 2010).

OTTENSMANN, J. R. (2000), Economic value of selected activities of the catholic diocese of Cleveland: Final report. Indiana University-Purdue University Indianapolis, School of Public and Environmental Affairs, Center for Urban Policy and the Environment.

RICKMAN, D.S. (2009), Neighborhood historic preservation status and housing values in Oklahoma County, Oklahoma. Journal of Regional Analysis and Policy 39(2), 99-108.

MACPHERSON, D. A. / SIRMANS, G. S. / ZIETZ, E. N. (2005), The composition of hedonic pricing models. Journal of Real Estate Literature 13(1), 3-43.

ULRICH, F. (2010), 300 churches, mosques and temples - so much religious is Hamburg. Hamburger Abendblatt, February 13/14, 2010 (in German).

_. (2010), 50,000 Muslims regularly visit mosques in Hamburg. Hamburger Abendblatt, May 14, 2010 (in German).

WILHELMSSON, M. (2000), The impact of traffic noise on the values of singlefamily houses. Journal of Environmental Planning and Management 43(6), 799-815. 


\section{Appendix}

Table 3 Descriptive Statistics of POW Indicators

\begin{tabular}{|l|rrrrr|}
\hline & $\begin{array}{c}\text { Number of } \\
\text { properties }\end{array}$ & $\begin{array}{c}\text { Mean year of } \\
\text { construction }\end{array}$ & $\begin{array}{c}\text { Mean floor } \\
\text { space }\end{array}$ & $\begin{array}{c}\text { Mean CHIME } \\
\text { DAY_INDEX }\end{array}$ & $\begin{array}{c}\text { Mean CHIME } \\
\text { NIGHT_INDEX }\end{array}$ \\
Denomination & (in kilometers)
\end{tabular}


Table 4 Descriptive Statistics of POW Indicators for Property Portfolio

\begin{tabular}{|l|rrrrr|}
\hline & $\begin{array}{c}\text { Number of } \\
\text { properties }\end{array}$ & $\begin{array}{c}\text { Mean year of } \\
\text { construction }\end{array}$ & $\begin{array}{c}\text { Mean floor } \\
\text { space }\end{array}$ & $\begin{array}{c}\text { Mean CHIME } \\
\text { DAY_INDEX }\end{array}$ & $\begin{array}{c}\text { Mean CHIME } \\
\text { NIGHT_INDEX }\end{array}$ \\
Denomination & 2,842 & 1922.2 & 483.4 & 1.40 & 0.72 \\
(in kilometers)
\end{tabular}




\section{Hamburg Contemporary Economic Discussions}

(Download: http://www.uni-hamburg.de/economicpolicy/hced.html)

BRANDT, S. / MAENNIG, W. / RICHTER, F.: Do places of worship affect housing prices? Evidence from Germany, 2013.

ARAGÃO, T. / MAENNIG, W.: Mega Sporting Events, Real Estate, and Urban Social Economics - The Case of Brazil 2014/2016, 2013.

MAENNIG, W. / STEENBECK, M. / WILHELM, M.: Rhythms and Cycles in Happiness, 2013.

RICHTER, F. / STEENBECK, M. / WILHELM, M.: Nuclear Accidents and Policy: Notes on Public Perception, 2012.

MAENNIG, W.: London 2012 - das Ende des Mythos vom erfolgreichen Sportsoldaten, 2012.

MAENNIG, W. / WELLBROCK, C.: London 2012 - Medal Projection Medaillenvorausberechnung, 2012.

MAENNIG, W. / RICHTER, F.: Exports and Olympic Games: Is there a Signal Effect?, 2012.

MAENNIG, W. / WILHELM, M.: Becoming (Un)employed and Life Satisfaction: Asymmetric Effects and Potential Omitted Variable Bias in Empirical Happiness Studies, 2011.

MAENNIG, W.: Monument Protection and Zoning in Germany: Regulations and Public Support from an International Perspective, 2011.

BRANDT, S. / MAENNIG, W.: Perceived Externalities of Cell Phone Base Stations - The Case of Property Prices in Hamburg, Germany, 2011.

MAENNIG, W. / STOBERNACK, M.: Do Men Slow Down Faster than Women?, 2010.

DU PLESSIS, S. A. / MAENNIG, W.: The 2010 World Cup High-frequency Data Economics: Effects on International Awareness and (Selfdefeating) Tourism, 2010.

BISCHOFF, O.: Explaining Regional Variation in Equilibrium Real Estate Prices and Income, 2010.

FEDDERSEN, A. / MAENNIG, W.: Mega-Events and Sectoral Employment: The Case of the 1996 Olympic Games, 2010.

FISCHER, J.A.V. / SOUSA-POZA, A.: The Impact of Institutions on Firms Rejuvenation Policies: Early Retirement with Severance Pay versus Simple Lay-Off. A Cross-European Analysis, 2010. 


\section{Hamburg Contemporary Economic Discussions}

(Download: http://www.uni-hamburg.de/economicpolicy/hced.html)

33

FEDDERSEN, A. / MAENNIG, W.: Sectoral Labor Market Effects of the 2006 FIFA World Cup, 2010.

AHLFELDT, G.: Blessing or Curse? Appreciation, Amenities, and Resistance around the Berlin "Mediaspree", 2010.

FALCH, T. / FISCHER, J.A.V.: Public Sector Decentralization and School Performance: International Evidence, 2010.

AHLFELDT, G. / MAENNIG, W. / ÖLSCHLÄGER, M.: Lifestyles and Preferences for (Public) Goods: Professional Football in Munich, 2009.

FEDDERSEN, A. / JACOBSEN, S. / MAENNIG, W.: Sports Heroes and Mass Sports Participation - The (Double) Paradox of the "German Tennis Boom", 2009.

AHLFELDT, G. / MAENNIG, W. / OSTERHEIDER, T.: Regional and Sectoral Effects of a Common Monetary Policy: Evidence from Euro Referenda in Denmark and Sweden, 2009.

BJØRNSKOV, C. / DREHER, A. / FISCHER, J.A.V. / SCHNELLENBACH, J.: On the Relation Between Income Inequality and Happiness: Do Fairness Perceptions Matter?, 2009.

AHLFELDT, G. / MAENNIG, W.: Impact of Non-Smoking Ordinances on Hospitality Revenues: The Case of Germany, 2009.

FEDDERSEN, A. / MAENNIG, W.: Wage and Employment Effects of the Olympic Games in Atlanta 1996 Reconsidered, 2009.

AHLFELDT, G. / FRANKE, B. / MAENNIG, W.: Terrorism and the Regional and Religious Risk Perception of Foreigners: The Case of German Tourists, 2009.

AHLFELDT, G. / WENDLAND, N.: Fifty Years of Urban Accessibility: The Impact of Urban Railway Network on the Land Gradient in Industrializing Berlin, 2008.

AHLFELDT, G. / FEDDERSEN, A.: Determinants of Spatial Weights in Spatial Wage Equations: A Sensitivity Analysis, 2008.

MAENNIG, W. / ALLMERS, S.: South Africa 2010: Economic Scope and Limits, 2008. 


\section{Hamburg Contemporary Economic Discussions}

(Download: http://www.uni-hamburg.de/economicpolicy/hced.html)

20

MAENNIG, W. / WELLBROCK, C.-M.: Sozio-ökonomische Schätzungen Olympischer Medaillengewinne: Analyse-, Prognose- und Benchmarkmöglichkeiten, 2008.

AHLFELDT, G.: The Train has Left the Station: Real Estate Price Effects of Mainline Realignment in Berlin, 2008.

MAENNIG, W. / PORSCHE, M.: The Feel-good Effect at Mega Sport Events - Recommendations for Public and Private Administration Informed by the Experience of the FIFA World Cup 2006, 2008.

AHLFELDT, G. / MAENNIG, W.: Monumental Protection: Internal and External Price Effects, 2008.

FEDDERSEN, A. / GRÖTZINGER, A. / MAENNIG, W.: New Stadia and Regional Economic Development - Evidence from FIFA World Cup 2006 Stadia, 2008.

AHLFELDT, G. / FEDDERSEN, A.: Geography of a Sports Metropolis, 2007. FEDDERSEN, A. / MAENNIG, W.: Arenas vs. Multifunctional Stadia Which Do Spectators Prefer?, 2007.

AHLFELDT, G.: A New Central Station for a Unified City: Predicting Impact on Property Prices for Urban Railway Network Extension, 2007.

AHLFELDT, G.: If Alonso was Right: Accessibility as Determinant for Attractiveness of Urban Location, 2007.

AHLFELDT, G., MAENNIG, W.: Assessing External Effects of City Airports: Land Values in Berlin, 2007.

MAENNIG, W.: One Year Later: A Re-Appraisal of the Economics of the 2006 Soccer World Cup, 2007.

HAGN, F. / MAENNIG, W.: Employment Effects of the World Cup 1974 in Germany.

HAGN, F. / MAENNIG W.: Labour Market Effects of the 2006 Soccer World Cup in Germany, 2007.

JASMAND, S. / MAENNIG, W.: Regional Income and Employment Effects of the 1972 Munich Olympic Summer Games, 2007.

DUST, L. / MAENNIG, W.: Shrinking and Growing Metropolitan Areas Asymmetric Real Estate Price Reactions? The Case of German Singlefamily Houses, 2007. 


\section{Hamburg Contemporary Economic Discussions}

(Download: http://www.uni-hamburg.de/economicpolicy/hced.html)

05

04

03

01

$04 / 2006$

$03 / 2006$

$02 / 2006$

$01 / 2006$

$04 / 2005$

$03 / 2005$

$02 / 2005$

$01 / 2005$
HEYNE, M. / MAENNIG, W. / SUESSMUTH, B.: Mega-sporting Events as Experience Goods, 2007.

DU PLESSIS, S. / MAENNIG, W.: World Cup 2010: South African Economic Perspectives and Policy Challenges Informed by the Experience of Germany 2006, 2007.

AHLFELDT, G. / MAENNIG, W.: The Impact of Sports Arenas on Land Values: Evidence from Berlin, 2007.

FEDDERSEN, A. / MAENNIG, W. / ZIMMERMANN, P.: How to Win the Olympic Games - The Empirics of Key Success Factors of Olympic Bids, 2007.

AHLFELDT, G. / MAENNIG, W.: The Role of Architecture on Urban Revitalization: The Case of "Olympic Arenas" in Berlin-Prenzlauer Berg, 2007.

MAENNIG, W. / SCHWARTHOFF, F.: Stadium Architecture and Regional Economic Development: International Experience and the Plans of Durban, October 2006.

FEDDERSEN, A. / VÖPEL, H.: Staatliche Hilfen für Profifußballclubs in finanziellen Notlagen? - Die Kommunen im Konflikt zwischen Imageeffekten und Moral-Hazard-Problemen, September 2006.

FEDDERSEN, A.: Measuring Between-season Competitive Balance with Markov Chains, July 2006.

FEDDERSEN, A.: Economic Consequences of the UEFA Champions League for National Championships - The Case of Germany, May 2006.

BUETTNER, N. / MAENNIG, W. / MENSSEN, M.: Zur Ableitung einfacher Multiplikatoren für die Planung von Infrastrukturkosten anhand der Aufwendungen für Sportstätten - eine Untersuchung anhand der Fußball-WM 2006, May 2005.

SIEVERS, T.: A Vector-based Approach to Modeling Knowledge in Economics, February 2005.

SIEVERS, T.: Information-driven Clustering - An Alternative to the Knowledge Spillover Story, February 2005.

FEDDERSEN, A. / MAENNIG, W.: Trends in Competitive Balance: Is there Evidence for Growing Imbalance in Professional Sport Leagues?, January 2005. 


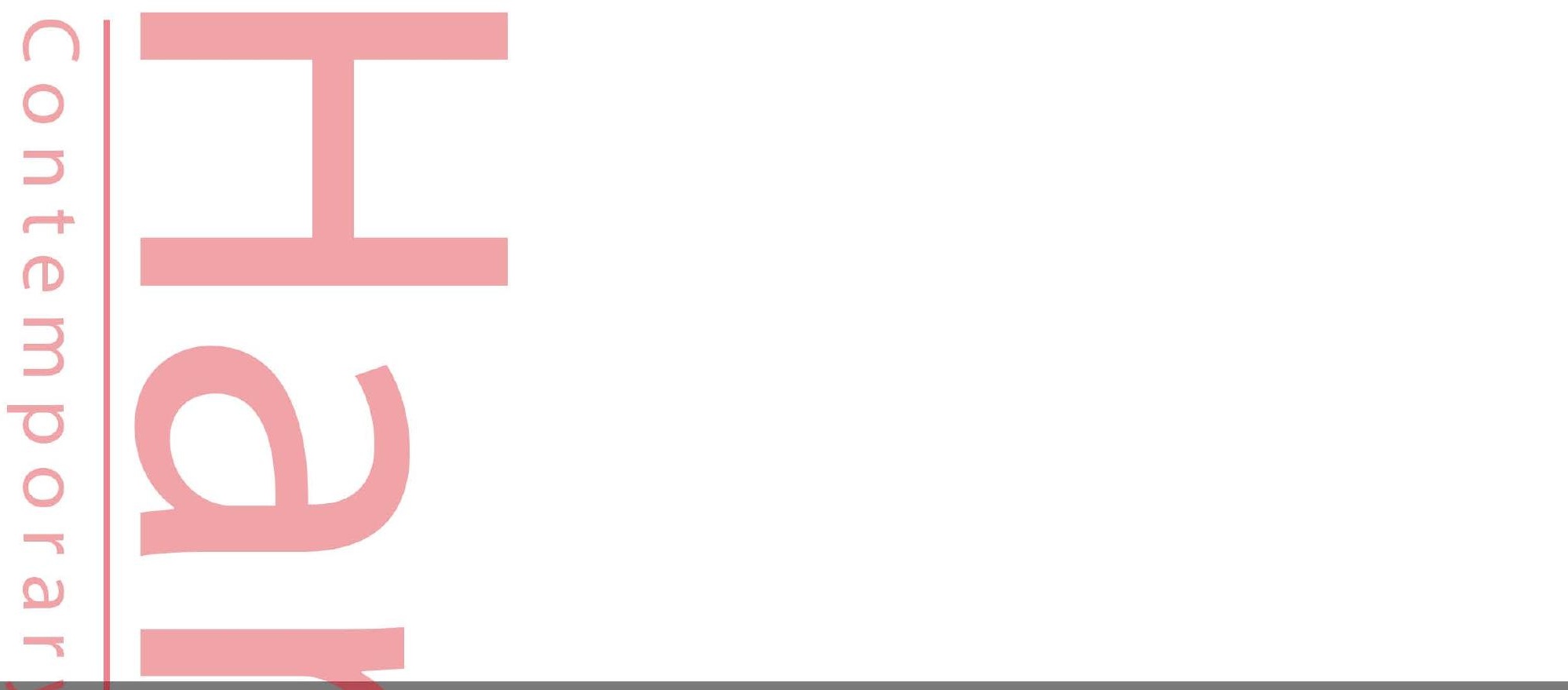

ISSN 1865-2441 (PRINT) ISSN 1865-7133 (ONLINE)

ISBN 978-3-942820-10-3 (PRINT) ISBN 978-3-942820-11-0 (ONLINE) 